\title{
Doing Post-Western sociology in Central and Eastern Europe before and after the Great Change: some epistemological questions
}

\author{
Svetla Koleva(1)
}

\author{
Correspondence: svetlakoleva2002@ \\ yahoo.com \\ The Great Change refers to the set \\ of economic, political, cultural and \\ institutional transformation \\ processes initiated since autumn \\ 1989 in the countries of Central and \\ Eastern Europe. If since the \\ geopolitical division following the \\ Second World War, these countries \\ have been part of the Soviet bloc \\ and have defined themselves as \\ popular democracies, the change in \\ political direction in 1989-1990 \\ marks the transition to liberal \\ democracy. \\ Institute of Philosophy and \\ Sociology, Bulgarian Academy of \\ Sciences, 13 A, Moskovska Street, \\ 1000 Sofia, Bulgaria
}

\begin{abstract}
Analyzing the sociology in Central and Eastern Europe before and after the Great Change in 1989, the article aims to present the main epistemological questions that Post-Western sociology raises for the discipline of sociology as a whole. The focus is put on a paradoxical feature in the development of sociology in the countries of Central and Eastern Europe: before 1989, under conditions of Marxist monoparadigmality, relative isolation of scientific cognition, and political and ideological pressure, sociological research in these countries was characterized by methodological rigor and conceptual innovativeness, while after 1989, in the context of institutionalized plurality of paradigms (polyparadigmality), and intensive scientific exchange, the dominant tendency is - for social scientists in the countries in question - to borrow methodologies, theories, and concepts from the Western sociological tradition, without analyzing the epistemic relevance of these loans with regard to the societies in which they are applied. This paradox is examined in terms of sociological production in two research fields: the general sociological theory of society and sociology of youth. Comparing studies and analyses carried out in these two fields in Central and Eastern Europe before and after the Great Change, the article demonstrates that Post-Western sociology is a valid research posture for a wide variety of sociological practices regardless of the concrete national, theoretical, or institutional frameworks in which researchers are working. Sensitivity to the context of research is what permits Post-Western sociology to eliminate cognitive hierarchies and inequalities and restores the epistemic autonomy of each cognitive practice, emphasizing the inevitable cultural variations in the interpretation of one and the same phenomenon and the impact of these variations on methodology. In this sense, Post-Western sociology raises important epistemological problems regarding the relationship between maintaining the disciplinary principles of sociological knowledge on the one hand, and the application of those principles in different epistemic contexts on the other hand. The main question could be formulated as follows: how does Post-Western sociology enrich the deontological and epistemological principles of the discipline and in what way does it contribute to developing its scientific project?

(Continued on next page)
\end{abstract}


(Continued from previous page)

Keywords: Sociology, Central and Eastern Europe, Great Change, Post-Western sociology, General sociology of "Socialist Society", Sociology of youth

\section{Introduction}

Post-Western sociology is a collective reflection on sociological practices, which-without competing with or opposing the dominant Western tradition-are developing in a constant movement between the logic of scientific argumentation employed in sociology and the specificity of the reality studied by sociology (Roulleau-Berger 2015, 2016; Roulleau-Berger and Peilin 2012; Roulleau-Berger and Peilin 2018; Xie and Roulleau-Berger 2017). In the perspective of the present day, the contribution of the creators of the Post-Western sociology paradigm has at least two aspects. On the one hand, they recognize that, despite the various kinds of dissymmetry that occurs in the production of sociological knowledge, sociology has always been practiced in a multiple number of "conceptual spaces" and by means of ethno-centric cognition. On the other hand, in the present-day context of circulation and globalization of knowledge, these scholars are advancing toward a theoretical, methodological, and epistemological conceptualization of these multi-situated forms of sociological experience.

These two levels, the epistemic and the epistemological, define the framework of this article. Starting from the epistemic level, which is doing Post-Western sociology in Central and Eastern Europe before and after the Great Change in 1989, I will try to formulate several epistemological questions that Post-Western sociology (as a research posture) raises for the discipline of sociology as a whole. The focus will be put on the following paradoxical feature in the development of sociology in the countries of Central and Eastern Europe: before 1989, under conditions of Marxist monoparadigmality, relative isolation of scientific cognition, and political and ideological pressure, sociological research in these countries was characterized by methodological rigor and conceptual innovativeness, while after 1989, in the context of institutionalized plurality of paradigms (polyparadigmality), and intensive scientific exchange, the dominant tendency is-for social scientists in the countries in question-to borrow methodologies, theories, and concepts from the Western sociological tradition, without analyzing the epistemic relevance of these loans with regard to the societies in which they are applied, which are in transition from a communist to a liberal social order. This paradox will be examined in terms of sociological production in two research fields: the general sociological theory of society and sociology of youth. By comparing studies and analyses carried out in these two fields in Central and Eastern Europe before and after the Great Change, I will try to demonstrate that Post-Western sociology is a valid research posture for a wide variety of sociological practices regardless of the concrete national, theoretical, or institutional frameworks in which researchers are working. Sensitivity to the context of research is what permits Post-Western sociology to eliminate cognitive hierarchies and inequalities and restores the epistemic autonomy of each cognitive practice, emphasizing the inevitable cultural variations in the interpretation of one and the same phenomenon and the impact of these variations on methodology. In this sense, PostWestern sociology raises important epistemological problems regarding the relationship between maintaining the disciplinary principles of sociological knowledge on the one 
hand, and the application of those principles in different epistemic contexts on the other hand. We may further raise the question: how does Post-Western sociology enrich the deontological and epistemological principles of the discipline and in what way does it contribute to developing its scientific project?

The article is structured in three parts. First, some landmark studies by sociologists in Central and Eastern Europe in the field of general sociological theory of socialist society and in the field of sociology of youth before the year 1989 are presented in order to emphasize how they differed from the concepts predominating in Western sociology at that time. Second, a short overview of sociological studies in the same countries in these two fields after the year 1989 is provided. Third, based on the discovered differences and contrasts, some challenges to the epistemology of Post-Western sociology are formulated. These challenges may be viewed as challenges to sociology as a whole, if we assume that Post-Western sociology is a research attitude, a way of doing sociology, regardless of the particular location and position of the researcher.

\section{Sociology in Central and Eastern Europe before the Great Change}

The analysis of sociology in Central and Eastern Europe in the period between 1945 and 1989, from the establishment of the Communist regimes and to their replacement, is based on two basic assumptions that are drawn from empirical experience. These assumptions are both an epistemological and an axiological conviction.

1. In contrast to the normative assertion that sociology as a product of modernity can only exist under conditions of democracy and a free market, here it is argued that the sociological rationalization of any society, regardless of its social, political, ideological type, is a "structuration of common experience" (Gardani 2013). Though sociology was born in Western Europe through a number of founding achievements (Fabiani 1993, 1994), there is more than a single matrix for the development of this science, more than a single invariable yardstick for measuring the validity of any produced sociological knowledge.

2. Cognition in sociology is a rational and methodical response to problems arising "here and now," problems that coexisting individuals encounter in their personal and social experience. Hence, the development of sociology is inseparable from that specific experience and the discipline has the task of problematizing both the experience and the ways in which it is studied. Taking this into account, sociological practice in Communist Central and Eastern Europe after the Second World War is viewed as a rationalization of the experience in the communist type of society of that time. The challenge to researchers is to understand that sociological practice in terms of its own measure rather than in terms of some previously given or presumed model.

Why was sociology able to exist and survive in the post-war non-liberal people's democratic societies in Central and Eastern Europe that lived under comparatively similar conditions of ideological, political, and social control, under the cognitive monopoly of the ideologized Marxist paradigm, and under various degrees (depending on the concrete country and period) of cognitive isolationism? This was the question that impelled my research efforts in the late 1990s in my capacity as a sociologist from a 
former Soviet bloc country formed during the 1980s in two different scientific traditions-the Bulgarian and the French, and a researcher who practiced sociology from the early 1990s in a variety of academic and institutional contexts of production and reproduction of sociological knowledge.

The comparative study on sociology in five former communist countries (Bulgaria, Poland, Hungary, former Czechoslovakia, former USSR) ${ }^{1}$ showed that the development of the discipline was possible through the construction of zones of relative institutional and cognitive autonomy (Koleva 2018). Here, it will be presented only a few aspects of sociological knowledge produced in and for the communist society of that time. In relation to Post-Western sociology, the basic question that interests us is, what kind of knowledge was being produced, and what was its cognitive and social value? As it was pointed out, here it will be overviewed the sociological studies in two sub-disciplines: the general theory of "Socialist society" and the sociology of youth.

The development of sociology in the communist countries of Central and Eastern Europe began with a cognitive paradox. How to study a society? The truth about it was previously defined, already known, and institutionally safeguarded? Having been recognized within the disciplinary system of "Marxist-Leninist science," sociology found itself in a theoretical and deontological framework where scientific truth was tied to political goals and subject to ideological criteria. From then on, and until the end of 1989, sociological practice went on in the context of the syncretism of the epistemological, political, and ideological normativity of institutionalized Marxism-Leninism.

Throughout the period under study, 1945-1989, the epistemic field of sociology practiced in Central and Eastern Europe was marked by two independent variables-the communist vision of the world as the axiological horizon, and Marxism-Leninism in its dual status as state ideology and dominant scientific paradigm. By analyzing the changes in thematic structure, the ways of problematization, and the models of argumentation in the general sociological theory of "Socialist society" and sociology of youth, we have identified two cognitive trends: on the one hand, the internal segmentation of the Marxist epistemic area which began from the very start of empirical research on social reality, and, on the other hand, the emergence of what may be called a postMarxist epistemic space-sociological conceptions that subjected the theoretical postulates of Marx's ideas to empirical testing, or sought analytical solutions outside these ideas, thereby standing at a distance from the dogmatic Marxist doctrine and ideological approach (Koleva 2018). Conceptual creativity in the national sociologies of the countries under study is both a condition and an expression of these two tendencies.

\section{General theory of "Socialist society"}

In the 1960s and 1970s, the new concepts served to designate politically unacceptable facts in a politically acceptable form. The terminological inventiveness of East European sociologists was especially keen when they were researching social differences and inequalities in socialist society-a society that, according to the ideology, should be, and was politically declared to be, free of class inequalities. The mismatch with the proclaimed model of a conflict-free equal society-a mismatch established as a result of

${ }^{1}$ The research project "Sociology in Central and Eastern Europe from the mid-1950s to 1989: The Road to the Challenges of the 1990s" was conducted with the financial assistance of the Research Support Scheme of the Open Society Foundation, and implemented in the period July 1999-June 2001. 
methodologically precise work-was presented in terms such as "objective interest intrinsic to every class" (Hochfield), "structural non-antagonistic conflict," "socioeconomic wage" (Wesołowski), "low-income categories" (Ferge), "bureaucratic equal system" (Machonin), and "social minimum" (Kyuranov).

New conceptualizations of this society appeared only in the 1980s, when growing economic and political crises shed light on the nature and structural principles of the "Socialist society" that had been under construction for several decades. The efforts to achieve a scientific understanding of "socialist" reality in the 1980s went on at a different pace and on different scales in the various national sociological communities depending on the depth and forms of crisis processes in each country, on the mobility of political limits set to possible activity, including cognitive activity, on the acquired research experience and extent of participation of sociologists in international scientific contacts. In any case, in the course of what would prove to be the last decade of the East European Communist regimes, the production of sociological knowledge in and about these societies went on in two basic forms. First, independently of one another, sociologists in the different countries attained similar conceptualizations of socialist society. Second, as a result of joint work with colleagues from the other communist countries and from countries outside the "Socialist Bloc," researchers developed original conceptions about the trends and processes common to societies regardless of their type of social formation.

Discrepancies and contradictions between the project of socialism (buttressed by ideological assertions and political reforms) and the actual functioning of society had accumulated over the years and became the object of intense reflection during the last decade of the communist regimes. The efforts to explain and interpret the specificities of the dysfunctions, cleavages, and paradoxes of those societies gave birth to some original concepts.

In Poland, Stanisław Ossowski elaborated the conception of three types of social order: the first of these is defined as related to collective representations where the social system is determined by the pressure of traditional patterns; the second is polycentric when social equilibrium is created by spontaneous interactions; the third is monocentric when social organization is regulated by the state and its institutions, as in the case of state socialism (Ossowski 1983). Based on the findings of his own social surveys, Stefan Nowak formulated the concept of the social vacuum to designate the missing link (civil society in Poland under state socialism) between the micro-level of the family and other primary groups and the macro-level of the state. According to him, the structure of Polish society during those decades resembled a "federation of primary groups united psychologically in an abstract national Gemeinschaft with very weak bonds between these two levels" (Nowak 1979: 128).

In Czechoslovakia, the Slovak sociologist Robert Roško elaborated the theory of the "social working circle" and the "home working circle," using it to explain the dualism in the functioning of the socialist economy. Labor-he pointed out-was performed both in the state "socialist sphere" and in the non-socialist, "domestic sphere" (Roško 1984).

The duality of the socialist system also attracted the attention of Bulgarian sociologists of the 1970s generation. The system of personal connections and "pulling strings" in which everyone was involved as participant or victim was conceptualized under the term "second network" (Raychev 1984). This network is engendered by two deficits that 
were proper to socialism: an economic deficit (of goods) and a power deficit (of real economic and political power). Essentially, the "second network" represents an exchange of statuses (that provided power in different spheres of society) and commodities in three basic directions: (a) statuses in exchange for commodities, (b) commodities for commodities, and (c) statuses for statuses. Thus, through the exchange of these two kinds of "goods," the second network compensated for the structural defects of the system.

The dualistic mode of functioning in economy, politics, culture evident in late communism was also studied and conceptualized by many Hungarian researchers, who designated it as a "second (secondary) economy" (Gábor 1978), a "shadow society" or a "second Hungary" (Forintos 1982), "disguised political platforms" (Pokol 1983), a "hidden dimension" (Bogár 1983), or a "latent," or "hidden" sphere (Bruszt 1984). The sociologist Elemér Hankiss made a theoretical synthesis of these ideas in his conception of the "second society" (1988). On the basis of the findings of his colleagues, he formulated nine criteria used to distinguish between the first and the second society in Hungary in the 1980s: homogeneity versus differentiation and integration; vertical versus horizontal organization; descendance versus ascendance; statization versus non-statization; centralization versus non-centralization; political versus socioeconomic dominance; ideology versus non-ideology; visibility versus invisibility; acceptance (legitimate, ideologically, and politically accepted sphere) versus non-acceptance (ambiguous legitimacy or illegitimacy). Applying these criteria to the study of various "second" areas in Hungarian society (second economy, second public, second culture, second social consciousness, second sphere of socio-political interaction, etc.), Hankiss reconsidered "the first-versussecond society dichotomy" and outlined "a hypothetical alternative society opposed to the now dominant first society and that the "second society" lies somewhere between the two as an intermediate sphere" (Ibid.: 39). In other words, Hankiss's analysis showed that whereas the "second society" is characterized by the absence of the main features of the first society, the "second society" had not yet fully developed the characteristics that were contrary to those of the "first society." The hypothetical alternative society would be marked by "fully developed opposite characteristics: horizontal organization, upward flow of power, predominance of non-state ownership, autonomy of social and economic actors, and differentiation cum integration" (Ibid.).

As for the conceptualization of that society, the general sociological theory of Hankiss (similar in vision and coinciding in the time of its appearance with concepts elaborated by sociologists in the other countries regarding the various forms of dualism of structures and ambivalence of processes in socialist society) enables us to notice an important particularity of sociological knowledge production. Made in different places by sociologists who were neither in direct nor in virtual (through publications) communication between themselves, the interpretation of socialism in terms of "three types of social order" (Ossowski), "social vacuum" (Nowak), "two working circles" (Roško), "second network" (Mitev, Raychev, Deyanov, Bundzhulov), "second society" (Hankiss) unfolded as a "co-production and co-construction of common knowledge" (RoulleauBerger 2016: 2$)^{2}$. It was not accidental that similar conceptions appeared in the

${ }^{2}$ That is how Laurence Roulleau-Berger defines the "post-Western space of knowledge" (2016). Although the concept of Post-Western Sociology refers to the sociological study of today's global world, its revolutionary heuristic potential lies in the possibility of setting sociological practices from the recent past in "relationships of equivalence" and to seeing them in the multiplicity of their connections and disconnections, exchanges and lack of exchanges, unequal development and common challenges. 
different European Communist countries after 30 years of construction of socialism. Those were years in which the proclaimed new society was able to objectify itself in practices that displayed systematic paradoxes and contrasts at the level of everyday life and provoked people's concealed resistance, evident indifference, daily inventiveness, and deceitfulness toward the system.

\section{Sociology of youth}

The 1980s also led to conceptual innovations that, based on international research experience, explained certain trends and phenomena common to the world at that time. Sociology of youth was a sub-discipline whose research object-perhaps more than that of any other sociological discipline-confronted sociologists coming from different national traditions, contexts, and social-political systems with common theoretical challenges and with the need to overcome their personal ideological, political, cultural preferences, and attitudes. In the 1960s, youth came out on the stage of various societies that differed by their degree of development and their economic and political order; in the next decades, youth asserted itself as a specific social actor whose presence could not be disregarded by societies striving for both stability and dynamic development. The changing position, role, and status of youth in all types of societies gradually turned, from a topic of interest for researchers in separate countries, into a focus of collective international sociological efforts which were institutionalized in 1975 in ISA Research Committee 34 Sociology of Youth, at the initiative of the Rumanian sociologist, Ovidiu Bădina. The Bulgarian sociologist, Petar-Emil Mitev, chairman of this research committee from 1982 to 1986, points out (Mitev 2016: 128)

People who made a special contribution to international collaboration in the 1970s and 1980s were scholars like Prof. Ovidiu Bădina (Rumania), Dr. Rudi Meyer (FRG), Prof. Jürgen Hartmann (Sweden), Prof. Peter Hexel (Austria), Dr. Sibylle Hübner-Funk (FRG), Prof. Vladimir Shubkin (USSR), Prof. Walter Friedrich (GDR), Prof. Arthur Meier (GDR), Prof. Vladimir Lisovsky (USSR), Prof. Władysław Adamski (Poland), Dr. Zoltán Békés (Hungary), Prof. Yedla Simhardi (India), Assistant Prof. Antonín Matějovský (Czechoslovakia), Prof. Ladislav Macháček (Czechoslovakia).

From a present-day perspective, we could say that the specific manifestations of common regularities in the development of youth throughout the world engendered a kind of international consortium that crossed the geo-political borders of the Cold War. The joint work on the empirical study of youth led to at least three achievements as regards the conceptual tools of sociology of youth and the theoretical treatment of youth problems.

Firstly, scholars demonstrated the need for complex study of youth problems, which was designated as "juventology" (Gospodinov 1980; Mahler 1983). This new concept was not invented out of academic eccentricity but reflected the search for the most adequate way (through interaction between sociology and other disciplines) to identify, study, and explain the topic in its complexity, mobility, homogeneity, and diversity. 
Secondly, the concept of "juventization" was created by which scholars designated not only the specific impact of youth on society but also the changes taking place in society as a result of the development and activity of youth. In other words, the term conceptualized the whole process of transformation of youth from an object of socialization into a subject of activities whose effects penetrate the entire society. Together with this, both sides of the process-socialization and juventization-were viewed as mutually determining. From its first appearance in 1975 in an article by Konstantin Gospodinov (dealing with the methodology of research on the effects of different types of education) and to Petar-Emil Mitev's elaboration and consistent enlargement of a sociological theory of juventization (1980; 1982; 1983; 1988), the concept was affirmed in sociology of youth as an analytical instrument for understanding the nature and importance of youth activity, and for operationalizing the manifestations of this activity (Hartman and Trnka 1984; Hartman and Stefanov 1984; Grootings and Stefanov 1986; Pavelka and Stefanov 1986; Velev 1985).

Thirdly, the study of youth in a historical and comparative perspective led to its conceptualization as a socio-biological group. It was seen as a product of the accelerated social development in the second half of the twentieth century, and in this sense, as a "comparatively new historical phenomenon" which both expresses and generates changes in social relations, and is characterized not only by its homogeneity in terms of age but also by its inner differentiation. This conception of youth, presented by PetarEmil Mitev at the 11th World Congress of ISA in New Delhi in 1986 when he completed his mandate as chairperson of RC 34 Sociology of Youth, proves convincingly that the development of scientific knowledge, including sociological, is possible only through the interaction of collective efforts and individual contributions. As for the cognitive value, heuristic potential, and incisiveness of this idea, the strongest proof of these are the data and research results that, 30 years after the text was first published, confirm the conceptualization of youth as a socio-biological group and of its main trends of development (Mitev 2016).

The case of sociology of youth is important not only and not so much in its theoretical achievements as with regard to the collective way they were made and by the fact that all colleagues have acknowledged the individual contribution of each researcher.

\section{Intermediate recapitulation}

The two cases presented here, those of the general sociological theory of socialist society and the sociology of youth, have two particularities that make them important for understanding Post-Western sociology. These fields show the following:

Firstly, in the conditions of a society in which knowledge is politically sanctioned and controlled, sociologists managed to discover the structural and historical specificity of society only when, in problematizing the phenomena under study, they stopped using theories meant to explain a different social-historical reality than that of the socialist society. The scientific categories and the analytic perspective defined by classical Marxian social theory or the contemporaneous conceptions of Western authors referred to a different historical experience. This mismatch between theories and reality was overcome when the researchers confronted the empirical data with their chosen theoretical model and thereby achieved thematizations and concepts that were able to explain the specificity of the phenomena under study. 
Second, in the time of the Cold War, sociologists from the two parts of the divided geopolitical world reached shared conceptualizations of a given phenomenon only when they remained in the field of scientific rationality, in the field of knowledge produced through comparative analyses and according to the currently operating models of control and verification of cognitive results.

The communist period in the development of sociology in Central and Eastern Europe ends with a paradox. The object of the "critical sociology of real socialism" revealing the structural principles and dysfunctions of this type of society disappeared into the historical past, and the societies that were starting on the road to democracy and market economy needed a new theory. This paradox is perhaps most heavily presented by Antoni Sułek.

They [the new generation of Polish sociologists in the 1980s] were oppositionminded and theoretically equipped, and they were not cabinet thinkers but studied society. They managed to create an excellent theory of real socialism, an excellent, very interesting theory of real socialism. Actually, they only laid the foundations of this theory and they started to develop this theory. And as they were developing this theory, the object of this theory collapsed. Their intellectual tools became useless and they had to start from the beginning (interview conducted on 24 March 2000, Warsaw, personal archive).

The most advanced theoretical attempt to understand and explain the society, the "critical sociology of real socialism" provides what is perhaps the strongest instance of fragility of cognitive outcomes and of the vocation of knowledge efforts.

\section{Sociology in Central and Eastern Europe after the Great Change}

Since the Great Change in 1989, sociologists in Central and Eastern Europe have been faced with a new object-unprecedented in history transition from "socialism" to capitalism, from "popular democracy" to "liberal democracy", from state-planned economy to a free market-and with the theoretical and methodological problems related to its conceptualization. How did the two areas of study-general sociological theory and youth sociology-develop in the post-1989 context of economic and political changes at the national, regional, and global levels?

The 30-year transition may be conventionally divided into two periods, the dividing line between which was the accession of the respective countries of Central and Eastern Europe to the European Union. This event has been chosen as a dividing line in view of the following. In terms of scientific research, the accession of a country to the EU results in access to programs and funding, the possibility of participation in international projects; more than that, it means participating in a certain scientific policy and a certain way of doing sociology.

Examining the sociological practice in the transitional societies in question, we observe at least three general trends.

First, during the first decade of transition, the attention of sociologists was drawn to the emergence or reconstruction (depending on the countries' historical experience) of civil society. The boom of NGOs and citizen action was an immediate response to the profound disconnection between state and society during socialism. The reconstruction 
of the political field with the creation of new political parties or the resurgence of those that existed until 1945-1948, with the emergence of new agents of civil action, became one of the most sought-after fields of research where sociologists competed with political scientists. As market principles permeated all spheres of society, sociological concerns turned toward social inequalities, social differentiation, and the excluded transition, employment policies, national minorities and their integration, new communication technologies and their economic, educational, social and cultural impact, bioethics and biopolitics, etc.

Second, in the first decade of the transition (or approximately until the entry of a country into the EU), there was predominantly a direct transfer of contemporary Western theories of modernity and postmodernity. These theories were applied to the liberal democracy transformation taking place without being analyzed with regard to their theoretical adequacy to the respective society. The concepts and theories that were most widely applied were those of modernization, of civil society, of social capital and rational choice, and of path dependency. To a certain degree, the situation that had taken place in the 1960s and 1970s was repeated: in the earlier time, the analysis of the new "socialist" society had likewise been conducted using theories that did not correspond to the historical specificity of the society.

Third, in the course of empirical study of societies in transition, original conceptions gradually emerged, aimed at interpreting the economic and institutional changes taking place in Central and Eastern Europe. Noteworthy among them is Ivan Szelényi's concept of "ever increasing 'varieties' of post-communist capitalism" (Szelényi 2013). Based on data from the research project "Poverty, ethnicity and gender during market transition" carried out in 1999 and 2000 by the international team in six European countries (Bulgaria, Hungary, Georgia, Poland, Romania, Slovakia), Szelényi identified three types of post-communist capitalism during the first decade of transition: neo-liberal, neopatrimonial, and "capitalism from below." He observed that during the last 15 years, one more form of post-communist capitalism had developed, that he called-following the terminology of Max Weber-neo-prebendalism. This was a stage of development of post-communist societies when all, or nearly all, social goods were privatized, "so the game can only continue if existing property rights are challenged $[\ldots]$ and the property re-redistributed" (Szelényi 2013: 19) to those who are loyal to the persons in power. The primary means for doing this are to treat political opponents as criminals and create a judiciary that is subordinated to the government, "to legitimate the expropriation and reallocation of property rights from one set of owners to another set of owners" (Szelényi 2013: 19-20). Szelenyi comes to an alarming conclusion, as the processes indicate that all three types of post-communist capitalism observed since the beginning of the transition evolve toward neo-prebendalism.

...neo-prebendalism is on the raise. It is a powerful tool; it appeals to broad audiences that one has to fight corruption, those who gained property and profit by exploiting privatization, to redistribute illegitimately made fortune [...]. Revenge is sweet... If you did not make it (you might have been unlucky, too honest, stupid, lazy or whatever...), you see yourself as a victim and you want revenge. Neoprebendalism: to punish the evil, the undeservingly successful and reallocate what they got to the victims, the unlucky ones who deserves better is a powerful 
ideology. It can be an effective tool to gain votes, majorities in parliaments and to serve finally 'justice'. Watch out... we are in dangerous territories (Szelényi 2013: 21).

Close to the idea of neo-prebendalism is the Hungarian sociologist Balint Magyar's conception of the post-communist mafia state (Magyar 2016). Magyar has studied the social-political metamorphoses in the Hungarian state system and the characteristics of the existing regime of management in Hungary. According to Magyar, the political reality in contemporary Hungarian society copies the structure of a mafia organization and the state institutions are the instrument of business in the sphere of politics. The main aim of this political business is for the ruling political elite to acquire hegemony.

The Bulgarian legal expert, Venelin Ganev, who has a $\mathrm{PhD}$ degree from Cornell University, is less radical in his designation of the developments during the early period of post-communism. He views the transition of Bulgarian society as a form of transformation, a denationalization of the state, and analyzes the cause of the dysfunctionality of the post-communist state structures. He sees the causes in "the unique institutional legacy of state socialism, the unusual structure of incentives that influence the behavior of the ruling elites, and the characteristic dynamic processes that have been unleashed during the radical change of foundational social interrelations connected with the concentration, management and distribution of resources" (Ganev 2007: 21).

As for sociology of youth, the evolution of this field after the Great Change follows a trajectory moving from the practice of Post-Western sociology to a hegemonic Western type of doing sociology. In the first decade of the transition, the rich tradition of youth studies in sociology seemed to have been interrupted. The national institutes of youth studies in the separate countries were dismantled, joint comparative studies were no longer made. Similar to the other sociologists, youth researchers from Central and Eastern Europe sought contacts with colleagues in Western Europe. The revival of research practice began after the accession of the countries to the EU; thanks to the framework programs for cooperation in the field of science and higher education. The way of organizing and functioning of the European scientific area suggests the appearance of new East-West asymmetries. Based on the experience of participants in European projects on the problems of youth from Central and Eastern Europe as well as Western Europe, it would be to point out the following asymmetries that seem worth further discussing ${ }^{3}$.

First, the theoretical model and the whole design of the projects are based on the characteristics and predominating trends of the national society to which belongs the research team that initiates and heads the projects. The specificities of the other societies under study only add local color to the general picture.

Second, certain questions arise during the preliminary survey and the fieldwork, but these are rarely discussed. Such not discussed questions may concern the relevance of the concepts and how they are adapted to the reality of each society, beyond the matter

\footnotetext{
${ }^{3}$ There are of course exceptions to hegemonic research practices. Only two international comparative research projects will be mentioned here: the European Social Survey (ESS), an academically driven crossnational survey conducted across Europe since 2001, which aims to examine the attitudes, beliefs, and behavior patterns of diverse population in more than 30 countries, and youth studies conducted in ten South East European countries between 2011 and 2018 supported by the Friedrich Ebert Stiftung (FES) and directed by Klaus Hurrelmann from the Hertie School of Governance (Germany).
} 
of linguistic translation, how they take into account the colloquial speech of different societies, the differences in meaning between speeches.

Third, at the final phase of a study, the national teams prepare reports on their own country and send the reports to the team responsible for the project, which makes a comparative analysis and summary.

It goes without saying that in most cases, the coordinators of research projects are research teams from West European countries. It also goes without saying that when we ignore the context in the course of formulating the research questions, this may result in a series of omissions and shortcomings.

Regarding the object of study, can we be sure the same term always designates the same phenomenon? Thus, can we be sure we are studying the same phenomenon in different contexts in different societies? When the topic of study is the transformation of civil society, the reconfiguration of public space, the emergence of new forms of civic mobilization, what is it that we are studying in societies with a long democratic tradition versus societies that are now reconstructing democracy after long years of life under authoritarian/totalitarian regimes? We must know what we are talking about and where we proceed from in each country, in order to be able to identify from the very start the multiplicity of practices that lead to the phenomenon that the term in question designates.

With regard to the whole set of instruments for the empirical study of a certain problem: samples, indicators, variables, questionnaires-all these instruments used to ensure the objectivity and validity of the results-may frustrate the scientific intentions of the researchers in case we fail to take into account the specificity of the context in which these instruments are applied.

With regard to analysis and interpretation, the societies that are at the same time the object of a given study and the context of the study's research activities have their particularities. These particularities cannot be captured if the theoretical and analytical framework is based on other reference points, foreign to that society.

\section{Conclusion: Summing up the main epistemological questions}

The discussion of the knowledge production in the fields of the general theory of society and sociology of youth in Central and Eastern Europe before and after the Great Change in 1989 has made it possible to identify two paradoxical processes in the practice of sociology that raise important epistemological questions to Post-Western sociology.

First, under conditions of geopolitical division in the time of the Cold War, sociologists in these countries exercised their discipline in a way that today can be defined as Post-Western sociology. "Playing" with the political and ideological context in which sociology was practiced, sociologists managed to get rid of the theoretical monopoly of Marxism-Leninism and to overcome the contradiction between the absence of a sociological theory about the new society (a theory of socialist society as a specific object of study) and its study as a historical specific phenomenon by using of methods and techniques established in the sociological discipline. Methodological rigor, conceptual creativity, and theoretical innovations characterize the work of those who seek to discover the structural truth of the socialist society. 
Second, under conditions of globalization of research activity and expanding international cooperation of scholars, we see growing dissymmetry in the production of sociological knowledge with the participation of representatives of different national traditions who have different weight on the international stage. New forms of research domination are appearing, the most frequent manifestations of which are the transfer or imposition of concepts, theories, methods from Western sociological tradition without analyzing their relevance to the Central and Eastern European societies in transition to a liberal social order.

These two contrary epistemic situations, however, lead to common theoretical and methodological lessons and raise the fundamental question concerning the epistemological consequences of the context for the production of sociological knowledge. Several lessons can be learned from the development of sociology in Central and Eastern Europe as a practice of knowledge production for two different historical type of society. First, the conceptual deficit will be characterizing any sociological practice as long as sociologists use theories meant to explain a different social-historical reality than that of the society studied. The scientific categories and the analytic perspective defined by such theories refer to a different historical experience and are not able to explain the specificity of the phenomena under study. Secondly, the excessive value attached to methodology-reduced to strict application of research methods and techniques-resulted in the reduction of sociological research to a technical procedure capable of producing data but not meanings. Reflecting on the adequacy of how research instruments are applied, and on the limits of their cognitive capacities, begins at the point when empirical information, though correctly produced in terms of methodology, no longer serves as a key to understanding the phenomena under study. Thirdly, the epistemological cleavage between the theoretical and empirical levels of sociological cognition led to the creation of mutually discrepant cognitive worlds-a situation that impeded not only sociological reflection on society but also the building of adequate scientific foundations for social action. Fourthly, as long as sociology functions in harmony with the surrounding context of argumentation (CoenenHuther 1997), the discipline is able to guarantee its own existence and that of the system of which it is a part. As soon as it put in question the system as the guarantor of the dominant social order, sociology begins to reveal the structural truth about society.

Insofar as sociology is always practiced in specific contexts, the main epistemological question is how sociology can continue to produce scientific knowledge about the social world, i.e., knowledge, the validity of which is not reducible to the conditions under which it was produced. In the Post-Western space of knowledge, in which sociological practices are viewed as "relationships of equivalence" (Roulleau-Berger 2016), this question embraces important epistemological challenges concerning context as an epistemic variable and contextualization as a research procedure. In every sociological study, attention must be focused on the way in which conceptions, concepts, and methods based on a specific social reality legitimize themselves as a science and communicate with each other; on the relation/relationship between the idea of universality of scientific knowledge and sociological practices situated and anchored in multiple contexts; on the validity and application of general epistemological principles that are supposed to guarantee the validity of knowledge produced in different contexts and by specific methodologies adapted to those contexts? On what means a scientifically credible and valid way of knowledge production. 
These research concerns fall within the main epistemological mission of sociology to construct and share a "common logical space for the construction of argumentation" (Berthelot 1996: 100). For Post-Western sociology, this means elaborating, on the basis of the variety of multi-situated sociological experiences, a common disciplinary language without which sociology could not fulfill its scientific vocation.

\section{Abbreviations \\ EU: European Union; FRG: Federal Republic of Germany; GDR: German Democratic Republic; NGOs: Non-governmental organizations; USSR: Union of Soviet Socialist Republics}

\section{Acknowledgements}

I would like to express my gratitude for the opportunity I have been given to participate in the workshop "What is Post-Western Sociology?" (27-28 October 2017, Nanjing University) organized by the International Associated Laboratory CNRS-ENS Lyon/CASS "Post-Western Sociology in Europe and in China," and by Nanjing University. My thanks go especially to Laurence Roulleau-Berger from Ecole Normale Supérieure de Lyon, to Cheng Boquing from Nanjing University, to Li Peilin from the Chinese Academy of Social Sciences, and to Xie Lizhong, Chinese Sociological Association, who have made it possible for me to join in this scientific event. I would also like to thank all the participants in the workshop for their comments, remarks, and questions.

\section{Author's contributions}

The entire text is my own work. The author(s) read and approved the final manuscript.

\section{Funding}

One part of the manuscript is based on the research project "Sociology in Central and Eastern Europe from the Mid1950s to 1989: The Road to the Challenges of the 1990s" which was conducted with the financial assistance of the Research Support Scheme of the Open Society Foundation (1999-2001).

Availability of data and materials

Not applicable.

\section{Competing interests}

Not applicable.

Received: 27 June 2020 Accepted: 14 October 2020

Published online: 09 November 2020

\section{References}

Berthelot, J.-M. 1996. Les vertus de l'incertitude. Le travail de l'analyse dans les sciences sociales. Paris: PUF [The Virtues of Incertainty. The Work of Analysis in the Social Sciences].

Bogár, L. 1983. A fejlödés ára. Gazdasagi nehézségeink föbb okainak törteneti aspektusa. Budapest: Közgazdasági és Jogi Könyvkiadó [The Price of Development. Historical Aspects of the Major Causes of Our Economic Difficulties].

Bruszt, L. 1984. Informális társadalom és legitimatás. Budapest: Társadalomtudományi Intézet [Informal Society and Legitimacy. Research Reports].

Coenen-Huther, J. 1997. Diversité de la sociologie et styles d'argumentation. Revue Européenne des Sciences Sociales 35 (107): 137-142 [Diversity of Sociology and Styles of Argumentation].

Fabiani, J.-L. 1993. Métaphysique, morale, sociologie. Durkheim et le retour à la philosophie. Revue de métaphysique et de morale 1: 175-191 [Metaphysics, Morals, Sociology. Durkheim and the Return to Philosophy].

Fabiani, J.-L. 1994. Epistémologie régionale ou épistémologie franciscaine? La théorie de la connaissance sociologique face à la pluralité des modes de conceptualisation dans les sciences sociales. Revue Européenne des Sciences Sociales 32 (99): 123-146 [Regional Epistemology, or Franciscan Epistemology? The Theory of Action in front of the Plurality of Modes of Conceptualization in Social Sciences].

Forintos, I. 1982. Honunk a hazában. Második gazdaság. Valóság/Reality 25 (1): 8-20 [Secondary economy in Hungary].

Gábor, I. 1978. The Second (Secondary) Economy. Acta Oeconomica. 22: 291-311.

Ganev, V.I. 2007. Preying on the State: The Transformation of Bulgaria after 1989. Ithaca: Cornell University Press.

Gardani, A. G. 2013. Le savoir sans fondements. La conduite intellectuelle de l'expérience commune. Paris: Éditions Vrin [Knowledge without Foundations. Intellectual Conduct of the Common Experience].

Gospodinov, K. 1980. Philosophical Introduction to Juventology. In Philosophska Misyl/Philosophical Thoutgh, 8 [Господинов, К. 1980. Философски увод към ювентологията. Философска мисъл. 8].

Grootings, P., and M. Stefanov, eds. 1986. Transition from School to Work. Sofia \& Vienna: Institute of Youth Studies and European Coordination Centre for Research and Documentation in Social Sciences.

Hankiss, E. 1988. The Second Society: is there an Alternative Social Model Emerging in Contemporary Hungary? Social Research 55 (1-2): 13-42.

Hartman, J., and M. Stefanov, eds. 1984. Youth in Europe. Integration through Participation. Sofia: IYS.

Hartman, J., and S. Trnka, eds. 1984. Integration of Youth into Society. Upssala: Upssala University.

Koleva, S. 2018. Totalitarian Experience and Knowledge Production. Sociology in Central and Eastern Europe 1945-1989. Leiden \& Boston: Brill.

Magyar, B. 2016. The Post-Communist mafia state: The case of Hungary. Sofia: Iztok-Zapad/East-Ouest [Mадяp, Б. 2016.

Посткомунистическата мафиотска държава: Случаят Унгария. София: Изток-Запад].

Mahler, F. 1983. Introducere in Juventologie. Bucuresti: Ed. ştiintifică şi enciclopedică [Introduction to Juventology]. 
Mitev, P.-E. 1980. The Modern Youth. Specific Moral Traits. Sofia: Narodna Mladezh [Митев, П.-E. 1980. Съвременният млад човек. Специфични нравствени черти. София: Народна младеж].

Mitev, P.-E. 1982. Sociology facing the Problems of Youth. Sofia: IYS

Mitev, P.-E. 1983. Jugend und Arbeit. In Ausbildung und Arbeitsplatzrisiko Jugendlicher. München: DJ Verlag Deutsches Jugendinstitut [Youth and Work In Education and Risks of Finding Jobs by Youth].

Mitev, P.-E. 1988. Youth and Social Change. Sofia: Narodna Mladezh [Митев, П.-E. 1988. Младежта и соииалната промяна. София: Издателство "Народна младеж"].

Mitev, P.-E. 2016. Bulgarians: Sociological Insights. Sofia: East-West [Митев, П.-Е. Българите: Сочиологически погледи. София: Изток-Запад].

Nowak, S. 1979. Przekonania i odczucia współczesnych. In Polaków portret własny, 122-145. Kraków: Wydawnictwo Literackie ["Convictions and Feelings of Contemporaries". In Polish Self-Portrait].

Ossowski, S. 1983. O osobliwościach nauk społecznych. Warszawa: PWN [On the Peculiarities of Social Sciences].

Pavelka, F., and M. Stefanov, eds. 1986. Rural Youth - Yesterday, Today, Tomorrow. Sofia: IYS.

Pokol, B. 1983. Az érdekképviseleti szervek és a politikai rendszer reformlehetőségei. Budapest: Institute of Social Sciences, Workshop Papers [Representative Institutions and the Reform Potentials of the Political System].

Raychev, A. 1984. Youth and "the Small Justice". Sofia: Narodna Mladezh [Райчев, A. 1984. Младият човек и "малката правда". София: Народна младеж].

Roško, R. 1984. Privlastňovací aspekt materiálnych podmienok života v zbližovaní robotníkov a inteligencie za socializmu. Sociológia/Slovak Sociological Review 15 (6): 618-631 [Possession and Material Living Condition in Bridging the Gap between Workers and Intelligentsia].

Roulleau-Berger, L. 2015. Inventer les sciences sociales post-occidentales. Socio, n5.

Roulleau-Berger, L. 2016. Post-Western Revolution in Sociology. From China to Europe. Leiden, Boston: Brill.

Roulleau-Berger, L., and Li Peilin, eds. 2012. European and Chinese Sociologies. A New Dialogue. Leiden: Brill Publishers. Roulleau-Berger, L., and Li Peilin, eds. 2018. Post-Western Sociology - from China to Europe. London \& New York: Routledge. Szelényi, I. 2013. Poverty and Social Structure in Transitional Societies. The First Decade of Post-Communism. Vol. 45. Plovdiv: Janet.

Velev, I., ed. 1985. Social Indicators in Comparative Youth Studies. Sofia: IYS, Bulgarian Sociological Association.

Xie, Lizhong, and L. Roulleau-Berger, eds. 2017. 社会学知识的建构.后西方社会学的探索/La fabrique des savoirs sociologiques. Explorations dans la sociologie post-occidentale. Beijing: Peking University Press.

\section{Publisher's Note}

Springer Nature remains neutral with regard to jurisdictional claims in published maps and institutional affiliations.

\section{Submit your manuscript to a SpringerOpen ${ }^{\circ}$ journal and benefit from:}

- Convenient online submission

- Rigorous peer review

Open access: articles freely available online

High visibility within the field

- Retaining the copyright to your article

Submit your next manuscript at $\boldsymbol{\nabla}$ springeropen.com 